\title{
Impact of Pyraclostrobin (F-500) on Crop Plants
}

\author{
Mansi Kanungo and Juhie Joshi ${ }^{\otimes}$
}

\begin{abstract}
Strobilurins, such as pyraclostrobin, belong to a fungicide group with preventative mode of action and are used around the world. After the launching of strobilurins, and with the evolution of this group of chemical products, the concept of disease control gained new perspectives especially when considering the advantages obtained by the action of positive physiological effects on plants. F-500 (pyraclostrobin) strobilurin, a new generation broad spectrum fungicide has been shown to cause changes in the metabolism of plants resulting in higher biomass and yield. Considering the ever increasing demand for food production with shrinking cultivable area day by day, it is necessary to go for agrochemicals which enhance the growth and development vis-à-vis productivity.
\end{abstract}

Keywords: biomass; pyraclostrobin; strobilurins; yield

\section{Introduction}

Strobilurins are an important class of fungicides that come from the discovery of Stroblilurus tenacellus, the mushroom fungus that causes wood-rotting. This isolated natural fungicide is thought to be used to protect the fungus against microbes in the decomposition of the wood. The discovery of strobilurins led scientist to isolate and produce synthetic strobilurins by chemically altering the compound to be able to tolerate sunlight (Vincelli, 2002). The strobilurins are a new class of systemic fungicides

Received: 15 May 2014 / Accepted revised version: 9 July 2014 / Published online: 3 September 2014

(C) Horizon e-Publishing Group

CITATION

Kanungo, M., \& Joshi, J. (2014). Impact of Pyraclostrobin (F-500) on Crop Plants. Plant Science Today, 1(3), 174-178. http://dx.doi.org/10.14719/pst.2014.1.3.60

AUTHOR'S AFFILIATION

School of Life Sciences, Devi Ahilya University, Indore (M.P.), India

CORRESPONDENCE

\ Juhie Joshi, Email: juhiejoshi@yahoo.com with a unique mode of action which targets the mitochondrial respiration by blocking the electron transport at the outer side of the cytochrome-bc1 complex (Balba, 2007).

After the launching of strobilurins, and with the evolution of this group of chemical products, the concept of disease control gained new perspectives especially when considering the advantages obtained by the action of positive physiological effects on plants (Venancio, Rodrigues, Begliomini, \& de Souza, 2003). Thus studies so far have concentrated mainly on phytohormone-mediated effects of strobilurins on the physiology of the plant senescence process. Therefore a longer period of photosynthetic active green leaf area has been suggested to be the main factor for yield increases obtained with strobilurin fungicides, because the increased photosynthetic period would increase the quantity of assimilate available for grain filling (Bertelsen, Neergaard, \& Smedegaard-Petersen, 2001). Over the past years, there has also been increasing evidence for direct influences of strobilurins on plant physiology. This physiological effect includes the so-called "greening," that is, even in the absence of challenge by pathogen attack; plants treated with strobilurins are intense green and look healthier than plants that have not been treated with strobilurin fungicides (Köehle et al., 2002; Kyveryga, Blackmer, \& Mueller, 2013). This suggested that, in addition to their fungicidal activity, strobilurins might also enhance the capability of plants to ward off pathogens.

\section{Types of strobulirins}

Strobilurins are natural products isolated and identified from specific fungi. Both natural (Fig. 1) and synthetic strobilurins (Fig. 2) are available.

\section{Mode of action}

Strobilurins are systemic fungicides and these exert their fungicidal action by blocking electron transport in the mitochondrial respiratory chain in fungi (Balba, 2007). With this unique mode of action the strobilurin is an important addition to the existing fungicides, in which 
recent broad- spectrum fungicide products have been largely based on sterol biosynthesis inhibitors (SBI).

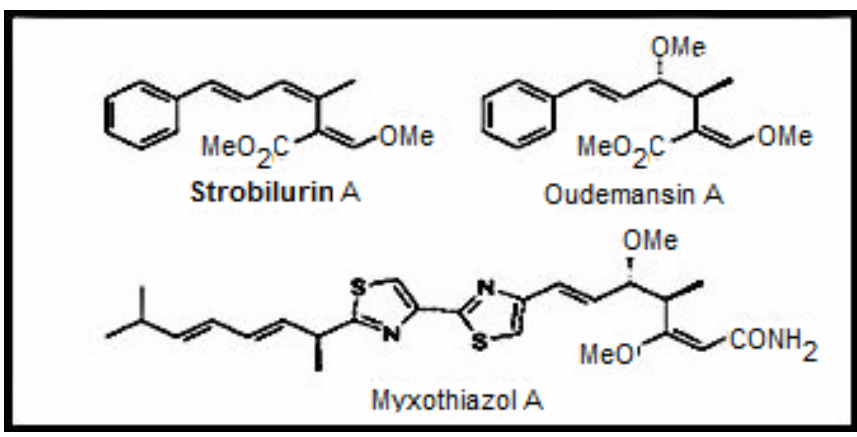

Fig. 1. Representative natural strobilurins (Bartlett et al., 2002)

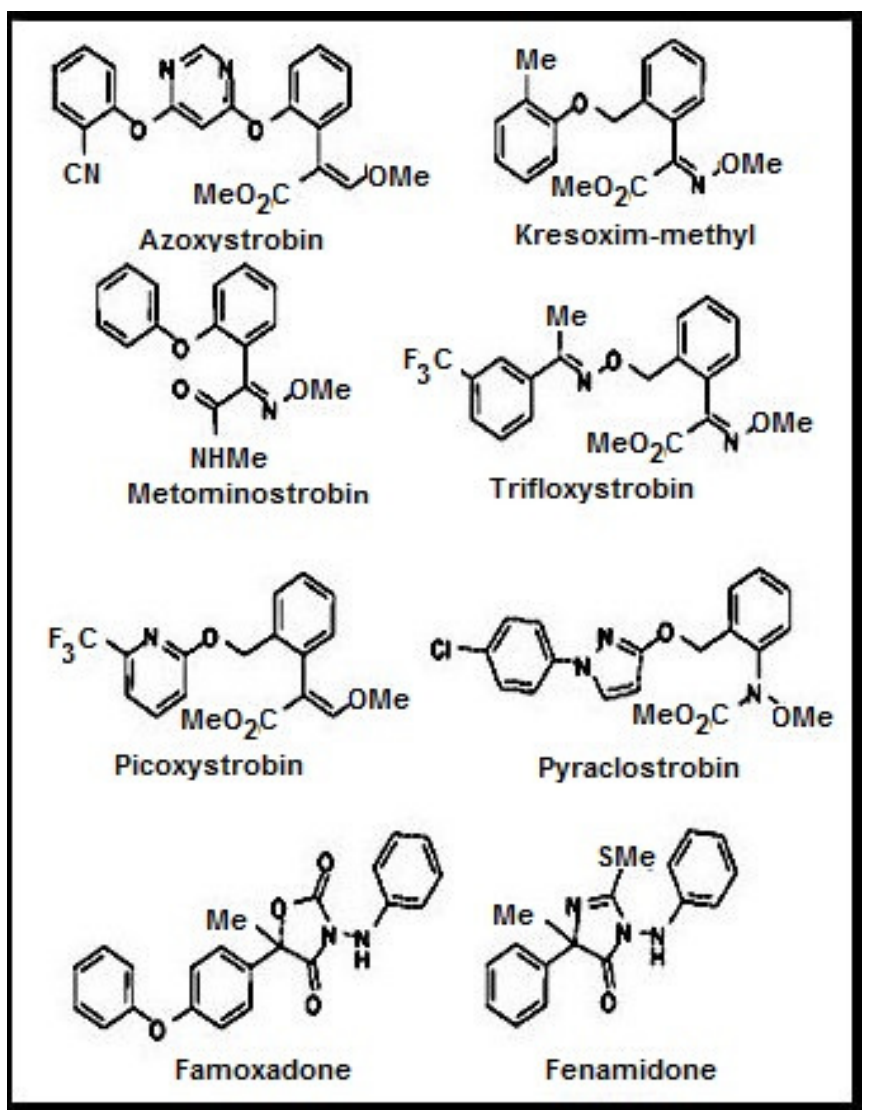

Fig. 2. The strobilurin fungicides, and famoxadone and fenamidone (Bartlett et al., 2002)

The mode of action of strobilurin fungicides is the inhibition of mitochondrial respiration by binding to the ubihydroquinone oxidation center of the mitochondrial bc1 complex (complex III), thereby blocking electron transfer (Sauter et al., 1999). The strobilurins bind to one specific site in the mitochondria, the quinol oxidation (Qo) site (or ubiquinol site) of cytochrome $b$ and thereby stop electron transfer between cytochrome b and cytochrome c, which halts reduced nicotinamide adenine dinucleotide (NADH) oxidation and adenosine triphosphate (ATP) synthesis (Brandt, Haase, Schaegger, \& von Jagow, 1993). This leads to the stopping of the energy production and the fungus will eventually die. Thus their mode of action is novel and new target-specific. They are more correctly referred to as the QoI fungicides.

\section{Pyraclostrobin fungicide (F500)}

Structure:

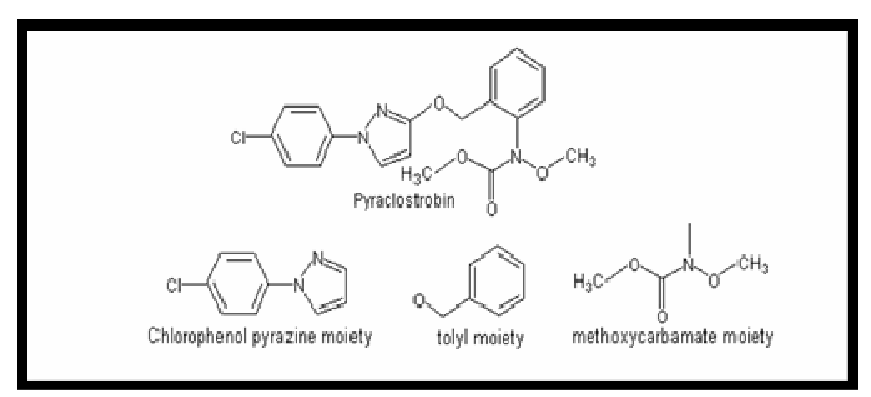

Fig. 3. Structure of Pyraclostrobin

Class: Strobilurin

Molecular-formula: $\mathrm{C}_{19} \mathrm{H}_{18} \mathrm{~N}_{3} \mathrm{O}_{4} \mathrm{Cl}$

IUPAC Name: methyl N-\{2-[1-(4-chlorophenyl)-1Hpyrazol-3-yloxymethyl] phenyl\} (N-methoxy) carbamate.

Pyraclostrobin (F500) belongs to strobilurin class of agricultural fungicides (Bartlett et al., 2002), used around the world, with a preventive mode of action (Grossmann, Kwaitkowski, \& Retzlaff, 1999). As a fungicide family, the strobilurins all have a common mode of action. Strobilurin fungicide pyraclostrobin (F-500) initially developed to control fungal pests showed growth promoting and yield enhancing qualities under field conditions. Later field trials using F-500 on healthy plants have substantiated these observations on plants like wheat and barley (Venancio et al., 2003; Köehle et al., 2002). It was reported that growth of soybean is enhanced by foliar spray of pyraclostrobin (Swoboda \& Pederson, 2009).

\section{Pyraclostrobin and biomass yield}

Strobilurins have shown some effects in boosting yields in wheat, corn, (Nelson \& Meinhardt, 2011), soybean (Henry, Johnson, \& Wise, 2011; Hill, Bowen, \& Hartman, 2013) and in other crops. Wheat grain yields were higher in a study by Ruske, Gooding, \& Jones (2003). The increased biomass had the biggest impact on grain yields. Some study revealed that fungicides applied in the absence of foliar disease did not produce non-fungicidal 
physiological effect or associated yield improvement and it was concluded that environmental conditions and assessment of disease levels should be used as a guide for foliar fungicide application on soybean (Swoboda \& Pedersen, 2009). Growth stimulation in plants with the strobilurin fungicides has been related to a reduction in the incidence of disease as well as increased nitrate uptake and assimilation in small grains (Köehle et al., 2003). Research has shown that pyraclostrobin was important in stimulating nitric oxide, a key messenger in plants (Conrath, Amoroso, Köhle, \& Sultemeyer, 2004).

\section{Pyraclostrobin and photosynthesis}

In wheat plants strobilurins are reported to enhance the net rate of photosynthesis in the treated leaves (Köehle, Grossmann, Retzlaff, Akers, \& Limburgerhof, 1997; Grossman et al., 1999; Häuser-Hahn, Baur, \& Schmitt, 2004; Oerke, \& Dehne 2005). Strobilurin application also extends the life of flag leaf by retention of higher chlorophyll content (Habermeyer, Gerhard, \& Zinkernagel, 1998; McCartney, Mercer, Cooke, \& Fraaije, 2007). These observations on photosynthesis indicate a higher amount of fixation of carbon by the application of strobilurin.

\section{Reduction and assimilation of Nitrogen}

The increase in biomass and production, obtained by application of pyraclostrobin, even in plants not affected by fungi, is of special interest for agricultural practices. Since an increase in biomass also requires greater assimilation of nitrogen, the NADH-nitrate reductase that catalyzes the first stage of nitrate assimilation, is considered as the relevant target for the effect in production caused by pyraclostrobin. The reduction of nitrate to nitrite is seen as the limiting step in the assimilation of $\mathrm{N}$ and thus highly regulated. Nitrate assimilation in wheat plants pulverized with pyraclostrobin was increased, in comparison with control plants (Köehle et al., 2003).

\section{Hormonal changes}

Köehle et al. (2003) confirm the effect of pyraclostrobin in the activity of ACC-synthase and synthesis of ethylene under conditions of stress and senescence in wheat. Hormonal levels of indol-3- acetic acid (IAA) and abscisic acid (ABA) were also determined. New wheat plants (Triticum aestivum L. cv. Kanzler) were treated in leaves with pyraclostrobin for 3 hours; pyraclostrobin inhibited the activity of ACC synthase and the levels of ACC in the tissue in up to $63 \%$ at $10-4 \mathrm{M}$. On the other hand, pyraclostrobin in a concentration of 10-8 to 10-4 M did not change the activity of in vivo ACC-synthase using enzymes extracted from detached buds and subjected to drying. This indicates that the fungicide may inhibit the synthesis of enzymes again. The endogenous levels of IAA may be the result of pyraclostrobin metabolism because this strobilurin breaks down to the natural precursor of IAA,
L-tryptophan in wheat (Köehle et al., 2003). As another effect of pyraclostrobin, it increases concentration of endogenous levels of abcissic acid (ABA) up to a maximum of $269 \%$ on the control.

\section{Retarded senescence after treatment with pyraclostrobin}

The detached leaves of a plant slowly lose chlorophyll, RNA, lipids and proteins, even if they are kept wet and are supplied with minerals. After exposing the wheat leaf discs to pyraclostrobin for 48 hours, the loss of chlorophyll, as a parameter of the progression of senescence, was inhibited by a growing concentration of strobilurin (Grossmann \& Retzlaff, 1997). Maximum retardation of leaf senescence, with up to $82 \%$ of the higher level of total chlorophyll in relation to the control was observed at 10-4 $\mathrm{M}$ of pyraclostrobin. The response to the dose in the retardation of senescence by pyraclostrobin had close correlation with decreasing levels of formation of ACC and ethylene and increase of IAA.

\section{Pyraclostrobin alleviates oxidative stress in plants}

In some cereals, mainly susceptible varieties of barley, the reactive oxygen forms may induce the formation of the so-called physiological leaf spot formation (Fig. 4.) (Wu \& Tiedemann, 2001, 2002a, 2002b), which causes severe losses in productivity (Baumer, Behn, Doleschel, Fink, \& Wybranietz, 2001). Resistant plants respond to oxidative stress with increase in the activity of antioxidative enzymes, such as superoxide-dismutases, catalases and peroxidases (Larson, 1997). In field tests conducted in Wo Palatinate, Germany, winter barley plants treated with pyraclostrobin did not develop symptoms, while flag leaves and lower leaves of untreated plants were covered by symptoms of physiological leaf spots, indicating some blocking reactions of radicals that opposed oxidative stress. When the activity of peroxidase in the flag leaf was evaluated, the plants treated with pyraclostrobin showed almost doubled enzymatic activity, which can contribute toward tolerance to stress. It is interesting that this effect, established five days after treatment with fungicide, persisted for over four weeks (Köehle et al., 2003).

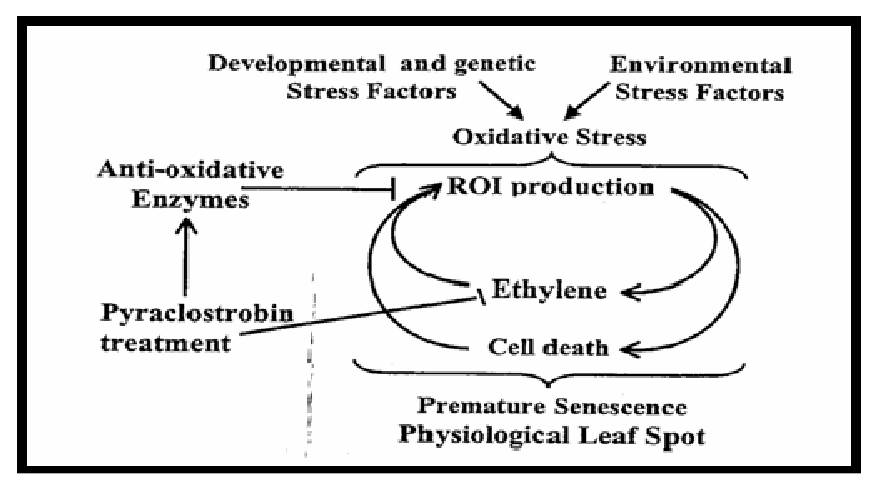

Fig. 4. Physiological and biochemical effect of pyraclostrobin 


\section{Conclusions}

The literature indicates role of strobilurin fungicide F-500:

- Enhances plant growth and biomass,

- Delays leaf senescence,

- Increases nitrate uptake, reduction and assimilation,

- Regulates phytohormonal level to overcome stress,

- $\quad$ Alleviates oxidative plant stress, and

- Enhances yield.

F-500 is now being used on Indian crops like soybean, fenugreek, maize, wheat. Strobilurin fungicide F-500 is thought to have an effect on plant growth and metabolism. This may be of particular significance in the tropical countries like India where various crops are largely grown without using fertilizers in the field. Even if the fertilizers are used application of pyraclostrobin can minimize the amount of fertilizers to be applied by enhancing the fixation of carbon and atmospheric nitrogen.

\section{References}

Balba, H. (2007). Review of strobilurin fungicide chemicals. Journal of Environmental Science and Health, Part B., 42, 441-451. http://dx.doi.org/10.1080/03601230701316465 PMid:17474024

Bartlett, D. W., Clough, J. M., Godwin, J. R., Hall, A. A., Hamer M., \& Parr-Dobrzanski, B. (2002). The strobilurin fungicides. Pest Management Science, 58, 649-662. http://dx.doi.org/10.1002/ps.520 PMid:12146165

Baumer, M., Behn, A., Doleschel, P., Fink, K., \& Wybranietz, J. (2001). Notreife durch parasiHire Blattver braunung. Getreide, 7, 92-97.

Bertelsen, J. R., Neergaard, E. D., \& Smedegaard-Petersen, V. (2001). Fungicidal effects of azoxystrobin and epoxiconazole on phyllosphere fungi, senescence and yield of winter wheat. Plant Pathology, 50, 190-205. http://dx.doi.org/10.1046/i.1365-3059.2001.00545.x

Brandt, U., Haase, U., Schaegger, H., von Jagow, G. (1993). Species specificity and mechanism of action of strobilurins. Dechema Monographien, 129, 27-38.

Conrath, U., Amoroso, G., Köhle, H., \& Sultemeyer, D. F. (2004). Non-invasive online detection of nitric oxide from plants and other organisms by mass spectroscopy. Plant Journal, 38, 1015-1022. PMid:15165192 http://dx.doi.org/10.1111/i.1365-313X.2004.02096.x

Grossmann, K., \& Retzlaff, G. (1997). Bioregulatory effects of the fungicidal strobilurin kresoxim methyl in wheat (Triticum aestivum). Pestic Science, 50, 11-20. http://dx.doi.org/10.1002/(SICI)1096-9063(199705)50 $: 1<11::$ AID-PS556>3.0.C0;2-8

Grossmann, K., Kwaitkowski, J., \& Retzlaff, G. (1999). Regulation of phytohormone levels, leaf senescence and transpiration by the strobilurin Kresoxin-methyl in wheat (Triticum aestivum). Journal of Plant Physiology,
154

805-808.

http://dx.doi.org/10.1016/S0176-1617(99)80262-4

Habermeyer, J., Gerhard, M., \& Zinkernagel, V. (1998). The impact of strobilurins on the plant physiology of wheat. 7th Intl. Conf. Plant Pathol. British Society of Plant Pathology, Edinburgh, UK.

Henry, R. S., Johnson, W. G., \& Wise K. A. (2011). The impact of a fungicide and an insecticide on soybean growth, yield, and profitability. Crop Protection, 30, 1629-1634. http://dx.doi.org/10.1016/j.cropro.2011.08.014

Hill, C. B., Bowen, C. R., \& Hartman, G. L. (2013). Effect of Fungicide Application and Cultivar on Soybean Green Stem Disorder. Plant Disease, 97, 1212-1220. http://dx.doi.org/10.1094/PDIS-12-12-1191-RE

Häuser-Hahn, I., Baur, P., \& Schmitt, W. (2004). Fluoxastrobin (HEC 5725) - biochemistry and chemodynamic behaviour of a new leaf systemic strobilurin fungicide. Pflanzenschutz-Nachrichten Bayer, 57, 437-450.

Kyveryga, P. M., Blackmer, T. M., \& Mueller, D. S. (2013). When do foliar pyraclostrobin fungicide applications produce profitable soybean yield responses? Online. Plant Health Progress.

http://dx.doi.org/10.1094/PHP-2013-0928-01-RS

Köehle, H., Grossmann, K., Retzlaff, G., Akers, A., \& Limburgerhof, G. (1997). Physiological effects of the new fungicide Juwel on yield in cereals. Gesunde Pflanzen, 4, 267-271.

Köhle, H., Grossmann, K., Jabs, T., Gerhard, M., Kaiser, W., Glaab, J., ... \& Herms, S. (2003). Physiological effects of the strobilurin fungicide F 500 on plants. In H. W. Dehne, U. Gisi, K. H. Juck, P. E. Russel \& H. Lyr (Eds). Modern Fungicides and Antifungal Compounds III, Bonn, Germany: Agroconcept GmbH.

Köhle, H., Grossmann, K., Jabs, T., Gerhard, M., Kaiser, W., Glaab, J., ... \& Herms, S. (2002). Physiological effects of the strobilurin fungicide F 500 on plants. H. W. Dehne, U. Gisi, K. H. Juck, P. E. Russel \& H. Lyr (Eds). Modern Fungicides and Antifungal Compounds III, Bonn, Germany: Agroconcept GmbH., 61-74.

Larson, R. A. (1997). Naturally occurring antioxidants. Boca Raton, New York: Lewis Publishers, CRC Press LLC.

McCartney, C., Mercer, P. C., Cooke, L. R., \& Fraaije, B. A. (2007). Effects of a strobilurin based spray programme on disease control, green leaf area, yield and development of fungicide-resistance in Mycosphaerella graminicola in Northern Ireland. Crop Protection, 26, 1272-1280.

http://dx.doi.org/10.1016/i.cropro.2006.10.027

Nelson, K. A., \& Meinhardt, C. G. (2011). Foliar Boron and Pyraclostrobin Effects on Corn Yield. Agronomy Journal, 103, 1352-1358. http://dx.doi.org/10.2134/agronj2011.0090

Oerke, E. C., \& Dehne, H. W. (2004). Safeguarding production pests, losses and crop protection in major crops. Crop Protection, 23, 275-285. http://dx.doi.org/10.1016/i.cropro.2003.10.001

Ruske, R. E., Gooding, M. J., \& Jones, S. A. (2003). The effects of triazole and strobilurin fungicide programmes on nitrogen uptake, partitioning, remobilization and grain $\mathrm{N}$ accumulation in winter wheat cultivars. The Journal of 

Agricultural
Science,
140
395-407.

http://dx.doi.org/10.1017/S0021859603003228

Sauter, H., Ammermann, E., Benoit, R., Brand,S., Gold, R. E., Grammenos, W., ... \& Wingert, H. (1995). Mitochondrial respiration as a target for antifungals: lessonsfrom research on strobilurins. In: Antifungal Agents. Discovery and Mode of Action. G. K. Dixon, L. G. Copping, D. W. Hollomon. Oxford: BIOS Scientific Publishers, p. 173-191.

Swoboda, C., \& Pedersen, P. (2009). Effect of Fungicide on Soybean Growth and Yield. Agronomy Journal, 101, 352-356. http://dx.doi.org/10.2134/agronj2008.0150

Venancio, W. S., Rodrigues, M., Begliomini, E., \& de Souza, N. L. (2003). Physiological effects of strobilurin fungicides on plants. Publ. UEPG Exact Soil Sciences, Agrarian Science \& Engineering, 9, 59-68.

Vincelli, P. (2002). QoI (Strobilurin) Fungicides: benefits and risks. The Plant Health Instructor. http://dx.doi.org/10.1094/PHI-I-2002-0809-02

Wu, Y.X., \& Tiedemann, A.V. (2001). Physiological Effects of Azoxystrobin and Epoxiconazole on Senescence and the Oxidative Status of Wheat. Pest Biochemistry and Physiology, 71, 1-10. http://dx.doi.org/10.1006/pest.2001.2561

Wu, Y. X., \& Tiedemann, A. V. (2002a). Impact of fungicides on active oxygen species and antioxidant enzymes in spring barley (Hordeum vulgare L.) exposed to ozone. Environmental Pollution, 116, 37-47. http://dx.doi.org/10.1016/S0269-7491(01)00174-9

Wu, Y. X., \& Tiedemann, A. V. (2002b). Evidence for oxidative stress involved in physiological leaf spot formation in winter and spring barley. Phytopathology, 92, 145-155. http://dx.doi.org/10.1094/PHYT0.2002.92.2.145 PMid:18943087. 